\title{
CORRESPONDENCE
}

\section{MEDICAL ARRANGEMENTS FOR THE EUROPEAN YOUTH SWIMMING AND DIVING CHAMPIONSHIPS}

Laurel Lodge, Wetherby Road, Leeds, LS17 8ND

To the Editor,

Dear Sir,

The Fourth European Youth Swimming and Diving Championships were to be held at Leeds from August 8 th - 11th, 1973. It was expected that 24 countries would be sending teams and that there would be about 400 competitors, all 15 years of age or under, together with coaches and officials. This was considered to be the largest event of its type ever staged in this country.

I was invited to act as Medical Officer to the Championships as early as August 1972. From previous experience I knew that one could not cover a major Championship and cope at the same time with everyday routine medical work. This period was therefore arranged as holiday and a locum-tenens engaged.

In order to limit prescription requirements to a minimum, a generous list of drugs, applications and dressings was drawn up, and kindly provided free of charge by Boots Chemists Ltd. A prominent acknowledgment was made in the programme.

Most of the visitors were to be housed at Boddington Hall, a modern University Hall of Residence on the outskirts of Leeds. The remainder booked into hotels in the City.

I planned to be on duty at the Westgate International Pool during all sessions of the Championships. This was in order to be available personally to advise coaches and team managers on problems related to the health of their teams; in particular to make decisions as to the advisability for particular swimmers to train or compete.

A nursing sister from my medical centre at Elida Gibbs Ltd., gave up part of her annual leave to assist me. With the Pool as Headquarters I hoped to provide and co-ordinate all medical care.

I approached the University Director of Medical Services, who agreed that he and his staff would visit anyone staying at Boddington Hall who was not well enough to travel to the pool. He also placed at our disposal his 16 bedded sick bay in the University Precinct, continuously staffed by nursing sisters, for any person who could not be adequately cared for in halls or hotels but where hospital admission would be unnecessary.
Two General Practitioners, whose practice areas included the hotels to be used, agreed to provide domiciliary cover if required.

The doctor in charge of the Sports Injuries Clinic at St. James's Hospital agreed to put his diagnostic and physiotherapy services at our disposal, on referral any day instead of the usual Monday clinic.

The same hospital also provided couches which were taken to the pool for use by the visiting teams for massage.

The local Director of the British Red Cross Society agreed to send one or two representatives to each session to care for the needs of the spectators.

In order that my colleagues should not receive calls on their services of a frivolous or unnecessary nature, it was arranged that all requests for attention should be made to me in the first instance. To ensure this an information sheet was given to every participant in the Championships. In this was included the following notice in English, German and French:

\section{Medical Advice and Treatment}

The official Medical Officer will be on duty at the International Pool, during the whole of the Championships. Competitors and Officials requiring treatment should report to the doctor at the pool. If any person is too ill to attend, the coach or team manager should telephone the doctor who will arrange a visit to the place of residence. Telephone No. etc.

I am pleased to report that the Championships were very successful. All sections of the planned medical services, except for the use of the sick bay, were called upon. What I did not anticipate was the need for the Medical Officer to be readily available during the two days prior to the commencement. It was surprising how many competitors arrived in Leeds with problems, both physical and emotional.

In conclusion, in the true spirit of European detente, I met, co-operated, exchanged gifts and fostered good relations with the accompanying team doctors from U.S.S.R., D.D.R., and Belgium. 
In common with many of my colleagues associated with sporting activities I have rather strong views about doctors accompanying representative teams abroad and feel it is important for a team to be accompanied by a doctor who is aware of the problems associated with both the competitor and the particular sport involved.
I have rather strong views about doctors accompanying representative teams abroad and feel it is important for a team to be accompanied by a doctor who is aware of the problems associated with both the competitor and the particular sport involved.

Yours sincerely,

STANLEY SHEFFRIN.

B.SC., M.B., M.R.G.G.P.

Honorary Medical Adviser N.E. Counties A.S.A. 